\section{Accomplishments of Sopron Foresters After Ten Years in Canada}

\author{
BY KALMAN J. ROLLER
}

Among forestry students graduating at the University of British Columbia, in May 1958, was a group of twenty-eight Hungarians. They were distinguished from the others only by a brilliant red and white cord sewn on their hoods, next to the green cord of forestry worn by all students. Red, white and green are the colors of the free Hungary and its wearers were the first of 141 graduates who, with 26 professors, left Sopron University, Hungary, and came to Canada in 1957.

The story began in October 1956 when Sopron students and professors joined freedom fighters in the Hungarian revolt. However, Soviet tanks rolled into the country in force to put a bloody end to the uprising. Then the Soproners with 200,000 other Hungarians fled to Austria and spread over the western world.

The Sopron students and professors were distributed throughout camps in Austria. The minister of Education in Vienna suggested a place, on the shores of the St. Wolfgang Lake, where the whole group might assemble. It was intended that the Sopron faculty would remain here permanently and function as a university in exile. Three full, 2 associate and 11 assistant professors, staff members of the University of Sopron, assembled in Wolfgang. In addition, 10 professionals who had been working with different research organizations in Hungary and who had fled to Austria at the same time, were invited to assist with teaching the forestry students. On November 17, 1956, classes began in earnest at the new location.

It very soon became apparent, however, that funds to operate the school permanently were limited because of the tremendous drain on Austria's resources, owing to the flood of refugees entering the country. Accordingly a search began for a new
Forest Research Laboratory,

Department of Fisheries and Forestry,

Winnipeg; formerly Dean

of the Forestry Faculty,

University of Sopron,

Hungary, who led the School

from Austria to Canada

and headed it until its

closing in Voncouver.

ODC 945.31: (711)

Manuscript received June 1968.

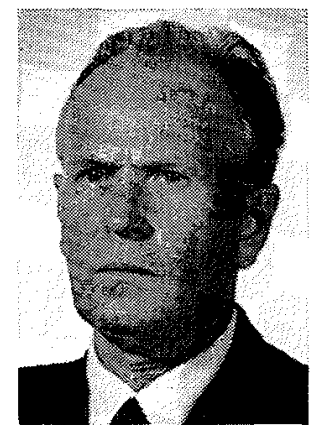

location to which the school could emigrate collectively. On November 22, 1956, a circular was sent to 30 heads of States. Some of the countries approached made offers with the stipulation that the student body would have to be broken up into smaller units that could be absorbed into several universities.

In Vienna, the school came to the attention of the Hon. Jack Pickersgill, then Canada's Minister of Immigration. He suggested to the Hon. James Sinclair, then Fisheries Minister, that the Sopron people might be transferred to the University of British Columbia in view of the Canadian need for foresters. The University President, Dr. Norman A. M. MacKenzie, when approached, enlisted the aid of the forest industry of British Columbia. Within 24 hours the Powell River Company had agreed to accommodate the students and professors in an empty construction camp at Powell River, British Columbia.

The head of the UBC forestry faculty, Dean George Allen, and the public relations officer for the Powell River Company, Fred McNeil, flew to Wolfgang to give the Sopron students and professors some idea of what Canada and British Columbia in particular were like. The Soproners were also told what they might expect in terms of continuing their education, summer employment, possibilities after graduation, and what the staff might do once the students had graduated. They showed a film called the "Powell River Story", a very good movie, and new at that time. The Soproners were amazed at the large logging equipment and the huge timber and paper machines in British Columbia. Logging equipment, such as Caterpillar tractors, big trucks, diesel yarders and so on, was practically unknown in Hungary. Forest conditions and management 


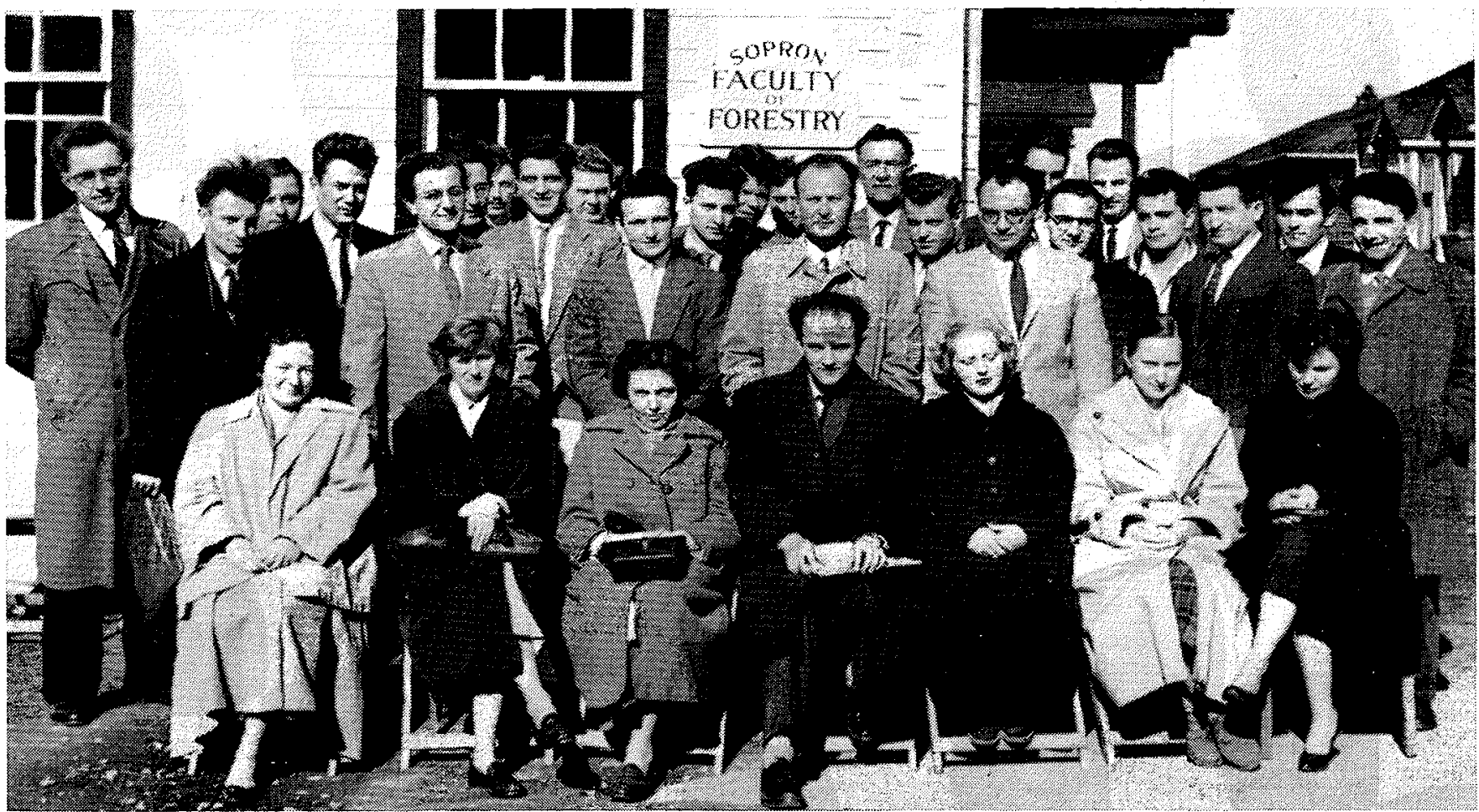

First graduates (Dean and two professors in the midst of the second row) in 1958 in front of the Hut of the Sopron Faculty at UBC.

were very different in Hungary from those in British Columbia.

The Sopron University sailed for Canada early in 1957 and, after spending the spring and summer in Powell River, 189 were enrolled as UBC students for the 1957-58 session. Life in a strange new country was not easy at first. Language was the most obvious barrier, and UBC set up special classes to instruct the newcomers in English. In over-crowded labs they worked and learned daily from 6:00 p.m. to midnight since class-rooms and lab time were allotted first to Canadian students. At first almost all instruction was given in Hungarian; later, when the professors and students improved their English, more and more lectures were given in English. Examinations however were in Hungarian throughout the four academic years during which the Sopron Faculty existed.

The educational system in Central European countries differed from the Anglo-Saxon teaching methods current in Canada. In Hungary great emphasis was placed on oral exams at the end of each academic term. A comprehensive examination was taken after the first and fourth academic years. The final exam involved defence of a thesis. Personal contact between professors and students played an important role in forestry education. Hungarian foresters have always regarded one another as brothers. This tradition was deeply rooted that the brotherhood of the Hungarian foresters had become an integral part of the intellectual and spiritual life of every person connected with the school. The members of this school were the heirs to a long and distinguished tradition of application of scientific values and methods for the care and management of Hungarian forests. At present, the forested area in Hungary is the lowest in Europe. Ecological and economic conditions make it necessary not only to apply the most intensive and refined skills of silviculture but also to preserve and protect the growing stock from the ever increasing demand of the inhabitants for wood. Silviculture and forest protection are therefore the main subjects in forestry education.

The history of the Sopron University was one of hardship and setbacks from the very beginning. The Forestry Faculty of the University was founded at Selmecbanya, now in Czechoslovakia, in 1809 as a Faculty of the Mining Academy. The first lecture was delivered by Professor Henrik Wilkens, a famous European biologist. The significance of this date becomes apparent when it is realized that the oldest forestry school in North America celebrated its first half-century in 1948. The oldest Faculty of Forestry in Canada, that of the University of Toronto, had its fiftieth birthday in 1957.

Twice during its history the university had had to find a new home. First it had to escape from Selmecbanya to Sopron in 1919 after the loss of the northern portion of Hungary to Czechoslovakia by the declaration of Trianon. Secondly, the faculty and student body fled in 1956 from Sopron to Vancouver where bereft of facilities, apparatus and books painfully acquired over many years, they began again. This was only rendered possible by assistance of a tradition which had been established and maintained with deep sacrifice.

Under the changed circumstances it became necessary to shape a new curriculum for the Sopron students, similar to that of the Forestry Faculty of UBC. However, emphasis on basic subjects such as botany, mathematics and mechanics was maintained and more time was spent on silviculture than was usual at UBC. In addition, from the second 


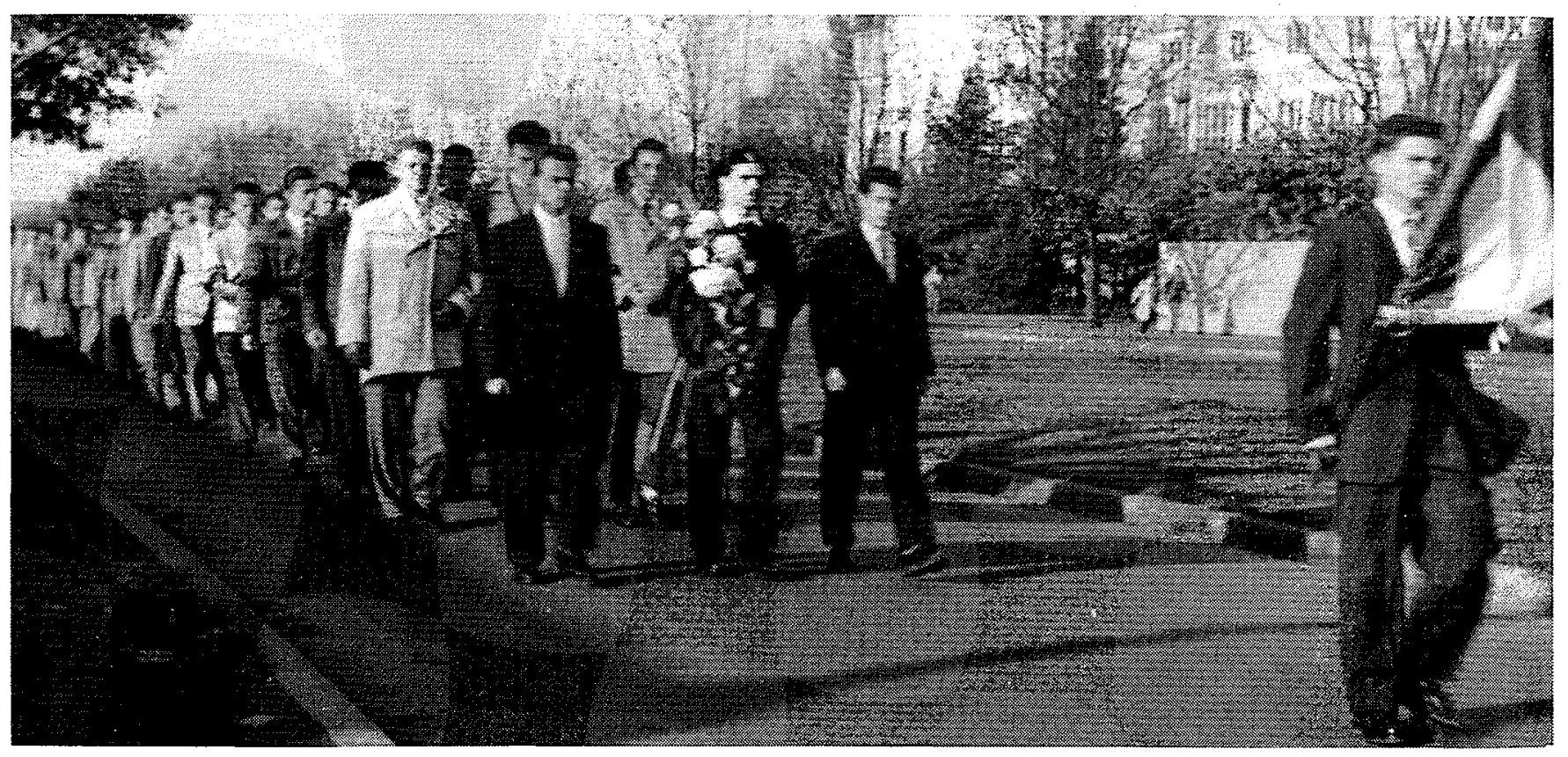

Annual march of the student body an the remembrance day (Oct. 23) of the Hungarian revolution at the UBC Campus.

year, Sopron classes attended courses in Forest Policy, Forest Administration, Economics and Fire Protection given in English by the UBC Forestry faculty.

By act of the British Columbia legislature the Sopron Faculty was absorbed as a division of the Faculty of Forestry of UBC. This status made it possible for Sopron students to receive a Bachelor of Science degree in Forestry with the words "equivalent to graduate forest engineer from Sopron University, Hungary" added.

Many Sopron students came to UBC expecting a free education but got only the $\$ 65.00$-a month subsistance, paid by the Government to all Hungarian refugees until May, 1958. Technical jobs for forestry students or graduates were not plentiful during those years because there was a slump in the industry. When the $\$ 65.00$ allowance was no longer paid the students had to borrow money from the university and take odd jobs if they wished to continue their studies. Many became disappointed with the situation and others wished to avoid getting into debt. Forty-eight of the 189 students accordingly left to seek a livelihood in fields other than forestry. These students did not all achieve university qualifications but they are nonetheless making their contribution to Canadian life, a contribution in which all the Sopron people may well take pride.

In May 1961, the last 23 out of the 141 students graduated in Vancouver and the story of a modern exodus ended on the green lawns of the University of British Columbia. Little Sopron, as it has been called, closed its Canadian doors forever, ending the tale of a modern-day flight to freedom by an entire school. And the graduates of this school not only increased Canada's corps of graduates in forestry, but their success endured as a monument to their own courage and the enlightened policy of the people of Cenada in offering refuge and help.

When the last of the Sopron students departed from UBC campus they left behind a memento in stone. It is a plaque, featuring two hands tightly clasped, representing Sopron and UBC.

During the past ten years the professors and students have spread over the North American continent making their own way and engaging in a variety of positions.

Six professors were employed by the Canada Department of Forestry and Rural Development, eight joined various universities in Canada and two moved to universities in the United States, two have taken overseas positions, one is working with the BC Forest Service, two are employed by mining companies, two with city organizations, one is supported by city welfare and two died of serious illnesses.

In 1966 the professional achievements of the Sopron graduates in Vancouver were surveyed by $L$. Adamovich and $\mathrm{O}$. Sziklai, both associate professors at the Forestry Faculty, UBC. The study was made possible by a grant from the K. L. Koerner Foundation. Their report showed that two of the 141 graduates returned to Hungary, 112 are working in Canada, 22 in the United States and 5 in Europe, and one died in a car accident. Thirty per cent of the graduates took post-graduate courses; 28 students obtained MSc and 14, PhD degrees at different universities in Canada and the United States. Seventy-one per cent have taken employment in forestry, twenty-two per cent with non-professional organizations and seven per cent with others. The average yearly earning was $\$ 7,600$ at the end of 1966.

Data were collected from a number of sources about the organizations in which the majority of Sopron graduates are employed. About 18 are employed by MacMillan Bloedell Ltd., British Columbia, ten with the BC Forest Service, nine with the Canada Department of Fisheries and Forestry and seven have taken teaching jobs at different universities in Canada and North America. 
This unique school no longer exists. But the former members of the staff and student body organized themselves into an association which serves as a link between them. The association publishes a periodical, the "Kapocs", twice a year; this brings information about the former Soproners to each member of the association. Each year the facutly and alumni gather and arrange a "Homecoming ball" in Vancouver to review friendships and keep alive the traditions brought from Sopron.

The first ten years, which were certainly the most difficult period in the life of the Soproners, are now over. During that period the Soproners have endeavored to contribute in worthwhile manner by placing themselves fully at the disposal of their new country. The years to come may bring more success to them. And one day, a historian will evaluate Canada's reception of these refugees as an immensely positive contribution to humanity.

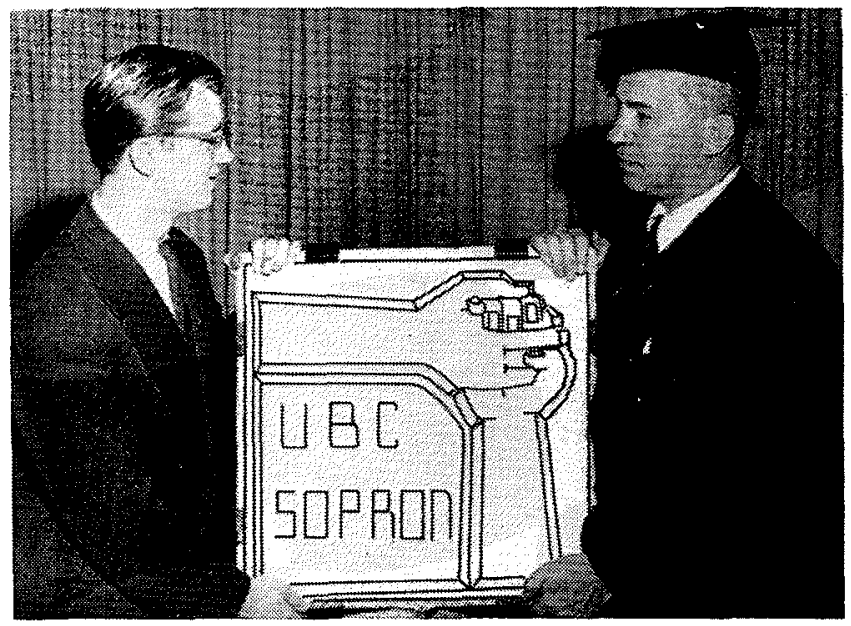

G. C. Andrew (right), Dean and Deputy to the President, UBC receives the memorial plaque from a Sopron graduate in 1961.

\section{Influence of stocking and density upon growth and yield of trees and stands of western hemlock.}

\section{Abstract of PhD Thesis Univ. of British Columbia}

Influence of stocking and density upon growth and yield of trees and stands of western hemlock. Variation of western hemlock (Tsuga heterophylla (Raf.) Sarg.) tree and stand growth were analysed to determine the relative importance of causative factors. Four phases in a stand's life-cycle were investigated (seedling establishment, juvenile growth, early stand formation, and middle-age). Detailed analyses of tree growth were made at the time of early stand formation ( 25 to 35 years). Stand growth and yield data (15 to 160 years) were analysed by multiple regression methods to ascertain the effects of varying density regimes on time and magnitude of maximum wood volume per acre.

In all stands studied, tree height was unaffected by variations in stand density. Detailed analyses of current breast-height radial growth indicated that factors of antecedent growth, tree d.b.h., stand density, age, and site quality were of decreasing importance in the order listed. Statistically, the best measures of stand were ratios of crown width and live crown length with total tree height, although stand basal area per acre was only slightly less significant.
Stand fertilisation with nitrogen stimulated tree radial growth and changed the relative concentrations of foliar nutrients within the crown. Limited (15 trees) biomass studies indicated that production per unit area of above-ground tree weight (oven-dry) increased linearly with greater stand density.

Yield increased directly in proportion to the fraction of the area occupied by trees (stocking) and curvilinearly with the degree of crowding (stand density) within the area occupied. Mean annual volume increment did not culminate even at stand densities of 500 square feet of basal area per acre.

Both intensive and extensive forest management were discussed. Within the Coastal hemlock zone there could be many advantages for a shelterwood regeneration system and two-storey high forest with western hemlock as a supplementary species.

\section{J. E. Osborn,}

Timber Branch,

Ont. Dept. Lands and Forests, Toronto. 